\title{
НАСИЛЬСТВО ЯК ДЕСТРУКТИВНИЙ ВЕКТОР РОЗВИТКУ СУСПЛЛСТВА. СЕКСУАЛЬНЕ НАСИЛЬСТВО
}

МАРИСЮК Костянтин Богданович - доктор юридичних наук, професор, професор кафедри кримінального права і процесу Національного університету «Јьвівська політехніка»

ORCID: 0000-0002-7483-3836

КАНЦІ Володимир Степанович - доктор юридичних наук, професор, професор кафедри кримінального права і процесу Національного університету «Львівська політехніка»

ORCID: 0000-0002-3689-4697

КАНЦІР Ірина Анатоліївна - кандидат економічних наук, доцент кафедри теоретичної та прикладної економіки Національного університету «Львівська політехніка"

ORCID: 0000-0002-1259-0381

DOI:10.32782/NP.2020.1.11

УДК 343.226 (477)

Исследовано негативнъй беномен насилия, направления жизнедеятельности, которое пагубно влияет на развитие общественнъх отношений. Сделана попьтка сбормировать отдельнье предложения и рекомендачии, имеюшие значение для совершенствования соответствующей юридической практики в Украине. Обращено внимание на особенности, специбику насильственнъих действий (в частности, сексуального, домашнего насилия), в условиях вспьлшки инфекиионнъих болезней (пандемии) как в Украине, так и планетарного масштаба.

Ключевъе слова. Насилие, Физическое насилие, сексуальное насилие, домашнее насилие, экономическое насилие, психологическое насилие, биотерроризм.

Постановка проблеми

Проблема насильства залишається актуальною, адже насильство - явище поширене, яке зустрічається в усіх сферах життєдіяльності людини. За попередніми інформативними даними, під час оголошеного весною карантину в Україні зросла кількість насильства, зокрема, сексуального, домашнього. Пояснюється це тим, що члени сім'ї цілодобово перебували, фактично, у «замкненому» просторі, в одному приміщенні, житлі.

Таким чином, численні виклики породжує нова континентальна реальність, характерними ознаками якої стають: ускладнення соціальних структур та соціальних зв'язків, зміна роду людської діяльності та взаємодії, планетарні спалахи інфекційних недуг, які однозначно можна класифікувати спланованим актом БІОТЕРОРИЗМУ всесвітнього масштабу (виділено авторами). Від адекватної відповіді на них залежить як майбутне конкретної особи, так і буття спільнот, народів, людства в цілому.

Одним із таких викликів є насильство в сучасному світі. За даними американського Центру Всеосяжного Миру (CSP), у всьому світі нараховувалося майже чотири десятки збройних конфліктів та війн, у яких брали участь 28 держав. Одна з таких війн триває в Україні. Шість мільйонів людей у нашій державі, за даними ООН, потерпають від різних видів насильства [1].

Стан дослідження
y науці кримінології, кримінального права, філософії права, дослідженню окресленого явища приділяють чимало уваги. 
Інтерес науковців у ніші, зокрема, кримінально-правової доктрини у цьому аспекті є очевидним, адже відповідні насильницькі діяння, в основному, посягають на життя чи здоров'я особи. Проте, вчені поняття насильства, зазвичай, розглядали у межах аналізу конкретного злочину, здебільшого щодо окремих його аспектів.

Відповідні дослідження здійснювали, зокрема, Л. А. Андрєєв, Ю. М. Антонян, Р. А. Базаров, ШІ. Б. Байрамів, В. Е. Берестова, О. І. Бойцов, В. І. Борисов, С. В. Бородін, ᄉ. П. Брич, І. О. Бандурка, О. І. Бугера, В. О. Владіміров, Б. В. Волжинікін, В. Г. Гончаренко, А. В. Горбунова, В. К. Грищук, О. Б. Грязнова, Д. О. Гниліцька,О. В. Губанова, О.М. Гумін, І. І. Давидович, А. В. Двойменний, Ф. М. Джавадов, А. О. Джужа, В. В. Ераксіна, С. О. Загороднюк, О. М. Ігнатов, К. І. Ілікчієва, К. В. Катеринчук, А. Н. Кирюхіна, І. Я. Козаченко, М. І. Коржанський, Г. К. Костров, С. М. Коч, А. Н. Красиков, Г. А. Крігер, Н. Ф. Кузнєцова, М. О. Ковальова, С. С. Косенко, А. Г. Козлюк, В. М. Куц, Р. О. Аевертова, А. В. Левицька, Т. Д. Аисько, А. С. Аукаш, А. М. Аарченко, Ю. І. Аяпунов, П. С. Матишевський, П. П. Михайленко, С. Б. Мєлєшев, А. М. Мартиросян, Д. П. Москаль, О. Ю. Мошицька, А.А. Наконечна, В. О. Навроцький, Б. С. Нікіфоров, В. І. Осадчий, М. І. Панов, А. О. Пінаєв, Е. П. Побігайло, С. П. Репецький,О. С. Рябчук, Р. Д. Сабіров, О. І. Санталов, М. М. Сенько, В. І. Сімонов, О. В. Синєокий, М. О. Сємикіна, М. В. Стерехов, Н. С. Таганцев, В. П. Тихий, І. С. Тишкевич, В. І. Ткаченко, А. П. Тузов, І. Я. Фойницький, М. І. Хавронюк, О. М. Храмцов, С. В. Чмут, С. Д. Шапченко, О. Б. Шигоніна, Т. Г. Шувалова, С. Н. Шпаковський та інші. Водночас, у кримінологічній теорії, кримінальному праві, філософії права досі не вирішеною є низка важливих і дискусійних питань.

Метою статті є дослідження негативного феномену насильства, напряму життєдіяльності, який згубно впливає на розвиток суспільних відносин. Зроблено спробу сформувати окремі пропозиції і рекомендацій, що мають значення для вдосконалення відповідної юридичної практики в Україні.

\section{Виклад основного матеріалу дослідження}

Аналіз ситуації, що склалась у сучасному світі показує, що насильство продовжує відігравати свою деструктивну роль у соціальних практиках і людській взаємодії: в міжособистісних і групових відносинах, в агресивних діях військових блоків і завоюваннях, військових заколотах, репресивних державно-політичних стратегіях i, звичайно, в міжнародному тероризмі. Оскільки чисто правовий контроль проявів насильства у будь-якій формі виявляється малоефективним, це, безперечно, актуалізує його подальший науковий аналіз і сутнісне викриття, результати якого мають імплементувати у громадську свідомість.

На цих підставах, чинні юридичні механізми, разом із всебічним соціальним контролем, зможуть більш ефективно стримувати зростання насильницьких практик i агресивних поведінкових стереотипів. Адже суспільство і держава припускає (легітимізує) насильство й примус лише у формі санкцій щодо злочинців або злісних порушників соціальних норм, які склалися і виправдані культурно-історичною традицією та правом. Феномен насильства завжди викликав суттєвий інтерес у науковців, що призвело до формування багатоманітних теорій у соціології, психології, філософії права, політології, конфліктології, кримінології тощо [2].

Термін насильство найчастіше трактується як відносини між людьми, що базуються на застосуванні сили, що перешкоджає самозахисту потерпілого через очевидну асиметрію можливостей (фізичних, моральних).

Мета насильства - заподіяння шкоду жертві, опосередком болю, страждання, приниження, під загрозою здоров'я та життя потерпілого.

У широкому тлумаченні поняття насильства, зазначає А. Гусейнов, воно є синонімом морального зла і включає в себе, поряд 3 убивством, брехню, лицемірство та інші моральні деформації. Таке широке розуміння насильства $є$ цінним саме тому, що привертається увага до його морального виміру. Разом 3 тим, воно має два недоліки:

1) втрачається власний зміст насильства; 


\section{Кримінальне право, кримінальний процес та криміналістика}

2) його заперечення набуває форми безсилого моралізування. Моралізаторський абсолютизм є однією 3 основних причин, через яку ідеї ненасильства сьогодні не знаходять так само належного відгуку в суспільстві, як і дві тисячі років тому, коли вони, власне, і виникли. За такого підходу до проблеми, виключається саме питання щодо будь-яких випадків морально виправданого застосування насильства [3, с. 35].

Насильство як асоціальне явище не тільки формує трагічні обставини для багатьох людей, але й створює криміногенні ситуації, які передують кримінальним правопорушенням проти безпеки, здоров'я і життя людини, що в цілому руйнує фундамент стабільності суспільства. У юридичній науці насильством вважаються умисні дії суб'єктів, спрямовані на спричинення болю і фізичної шкоди іншим особам, які піддаються психофізичному тиску (наприклад, погроза розправи) або умисним тілесним ушкодженням (травми, поранення, смерть); на міжособистісному (колективному) рівні - це хуліганство, розбій, бандитизм, тероризм, вбивства тощо. Подібні дії та санкції відповідальності за них кваліфікуються нормами закону як злочини [2].

Важливим чинником, який призводить до поширення насильства в суспільстві, є ціннісна дезорієнтація сучасної людини. Регрес гуманності, нетерпимість і жорстокість людей починаються з дезінтеграції внутрішнього світу особистості, вакууму духовності. В умовах суспільної атомізації та фрагментації, «нова людина» 3 легкістю може змінювати як типи діяльності, так і цінності, ідеали, переконання. Вона «хворіє» на «моральну сліпоту», стає байдужою і нечутливою до проблем інших осіб.

У розумінні насильства важливими є два моменти:

а) те, що одна воля підпорядковує собі іншу;

б) те, що це відбувається внаслідок фізичного примусу, застосовуваного ззовні впливу [4]

Засадничою вважаємо диспозицію, подану $\mathcal{\lambda}$. Шнейдером: «Агресія - це будь-яка дія, яка має за мету спричинення фізичного або психічного збитку іншому суб'єкту; агресивна поведінка - така, при якій мають місце «згубні» для жертви наслідки; агресивність - це властивість особистості, що має вираз у готовності до агресивної поведінки» [5, c. 91$]$.

На нашу думку, агресія - це активна одномоментна дія (часто під впливом психосоматичних факторів), яка має на меті завдання шкоди іншій особі, а насильство - це перманентний стан поведінки особистості.

Здебільшого агресія виникає як реакція суб'єкта на фрустрацію і супроводжується емоційним станом гніву та ворожості.А власне готовність суб'єкта до агресивної поведінки вже розглядається як стійка риса особистості - агресивність [6, с. 5].

Погоджуємось 3 визначенням поняття «насильство», запропонованим В. Христенком: «Насильство - це форма прояву психічного і фізичного примусу стосовно однією із взаємодіючих сторін, що змушує цю сторону робити що-небудь усупереч своїй волі, бажанням, потребам» [7, с. 69].

Насильство - це процес, який не з'являється зненацька, а є певним циклом дій, мета - ескалація сили.

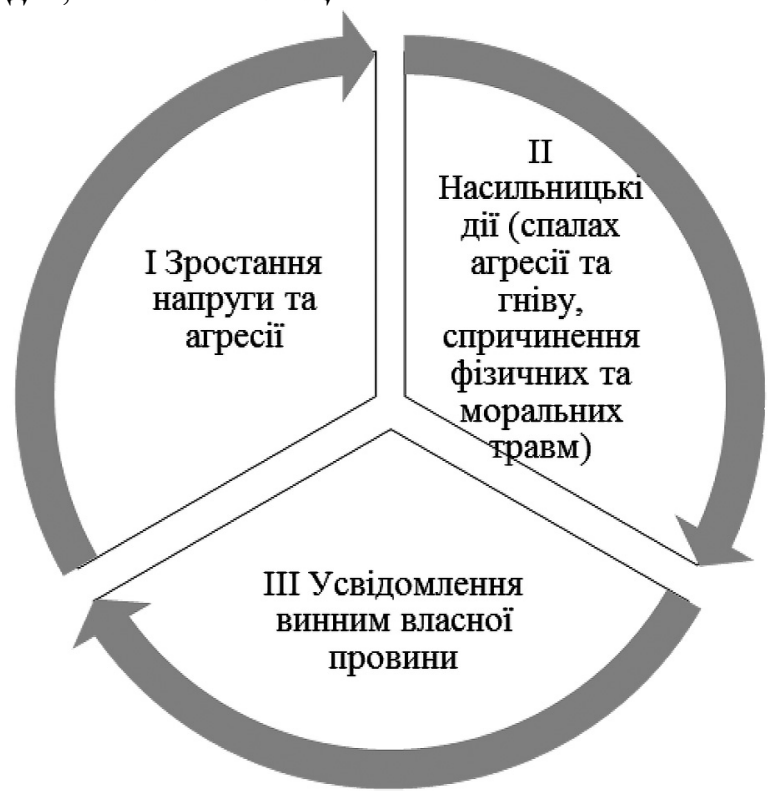

Рис. 1.1. Циклічність насильства

Насильство, зазвичай, викликане втратою контролю над агресивною поведінкою суб'єкта, почуттям безпорадності та сили й запланованої чи імпульсивної поведінки. Насильство, як вид злочинної діяльності, визначають три базові чинники: 
- потенційно можлива безкарність діянь злочинця;

- насильство відповідає його потребам, їх задоволенню;

- злочинна поведінка порушує добробут та права потерпілого.

Чинне законодавство виокремлюе фізичне насильство, домашнє насильство, сексуальне насильство, економічне насильство, психологічне насильство.

Моніторинг різних наукових платформ дає можливість погодитись із трактуванням насильства, запропонованого В. Христенком: «Насильство - це форма прояву психічного і фізичного примусу стосовно однією із взаємодіючих сторін, що змушує цю сторону робити що-небудь усупереч своїй волі, бажанням, потребам» [7, с. 69].

Згідно з рекомендаціями Всесвітньої організації охорони здоров'я (ВООЗ), насильство поділяється на три основні типи:

1) насильство проти себе самого (самонаправлене насильство);

2) міжособистісне насильство;

3) колективне насильство.

Світова спільнота тривалий час опікується питаннями протидії будь-яким видам насильства. Одним із заходів такої протидії стала Конвенція Ради Европи «Про запобігання насильству стосовно жінок і домашньому насильству та боротьбу з цими явищами» (Стамбульська конвенція), що була відкрита для підписання 11 травня 2011 року [8].

Необхідність дотримання Україною своїх міжнародних зобов'язань зумовлюе потребу в імплементації відповідних положень Конвенції в національне законодавство, що має завершитися створенням ефективних інструментів протидії насильству щодо жінок та домашньому насильству.

Відповідно до ст. 36 Конвенції, Сторони вживають необхідних законодавчих або інших заходів для забезпечення криміналізації таких форм умисної поведінки:

а) здійснення, без згоди, вагінального, анального або орального проникнення сексуального характеру в тіло іншої особи 3 використанням будь-якої частини тіла або предмета;

b) здійснення без згоди інших актів сексуального характеру з особою;

с) примушування іншої особи до здійснення без згоди актів сексуального харак-

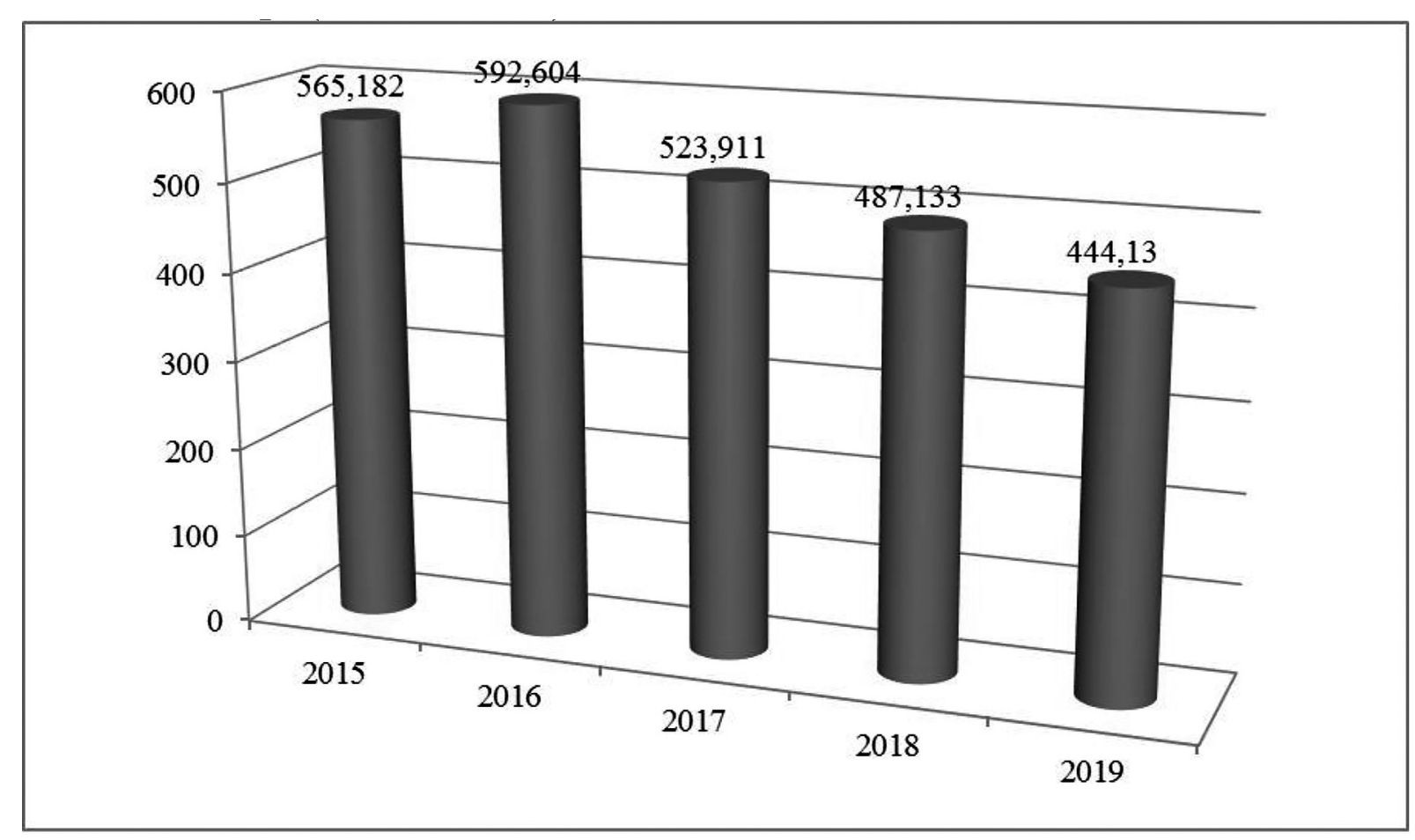

Рис. 2.1. Динаміка кримінальних правопорушень протягом 2015 - 2019 років.

За результатами офіційної статистичної інформації 


\section{Кримінальне право, кримінальний процес та криміналістика}

теру 3 третьою особою. При цьому, Згоду повинно бути надано добровільно як результат вільного волевиявлення особи, отриманого в контексті супутніх обставин.

Динаміка насильницької злочинності протягом попередніх п'яти років характеризується синусоїдними амплітудами коливань, найвище значення припадає на 2016 р. (592,604 тис.).

Найвищий відсоток розкриття насильницьких злочинів за період 2015 -2019 років, спостерігається у 2018 р. та становить $25,57 \%$. Мінімальний - у 2016 р. - 23,34\% (рис. 2.2).

За офіційними даними Генеральної Прокуратури, відносний показник злочинів проти статевої свободи та статевої недоторканості особи, що виявлені органами Національної поліції, у загальній структурі кримінальних правопорушень, становить 0,176237\%, що, безсумнівно, не відображає реальної картини (рис. 2.3). Адже, зазвичай, більшості сексуальних злочинів притаманна висока ступінь латентності.

До прикладу, згідно з уже згадуваним джерелом офіційної статистики, згвалтування, поряд з іншими сексуальними злочина- ми, має тенденцію до зниження (понад 40 \% за попередні 10 років). У зв'язку з цим, статеві злочини можна віднести до високолатентних, де частка прихованих - майже $90 \%$. Вiдомими причинами виникнення латентності зазначеного виду кримінальних правопорушень є соціальна незахищеність жертви, сором, страх, невпевненість в об'єктивності, неупередженості кримінального провадження.

Наше дослідження підтверджується даними National Centre for Victims of Crime (Національний центр допомоги жертвам насильства), майже $33 \%$ жінок (тобто кожна третя) до досягнення повноліття, як мінімум раз, зазнавали сексуального насильства. Аналогічна статистика серед чоловіків шокує не менше - жертвами сексуального насильства є більше $16 \%$ (тобто приблизно кожен шостий). Найчастіше згвалтувань зазнають підлітки, за статистикою, одна 3 чотирьох дівчат і один з шести хлопців можуть зазнати сексуального насильства, перш ніж їм виповниться 18 років [10].

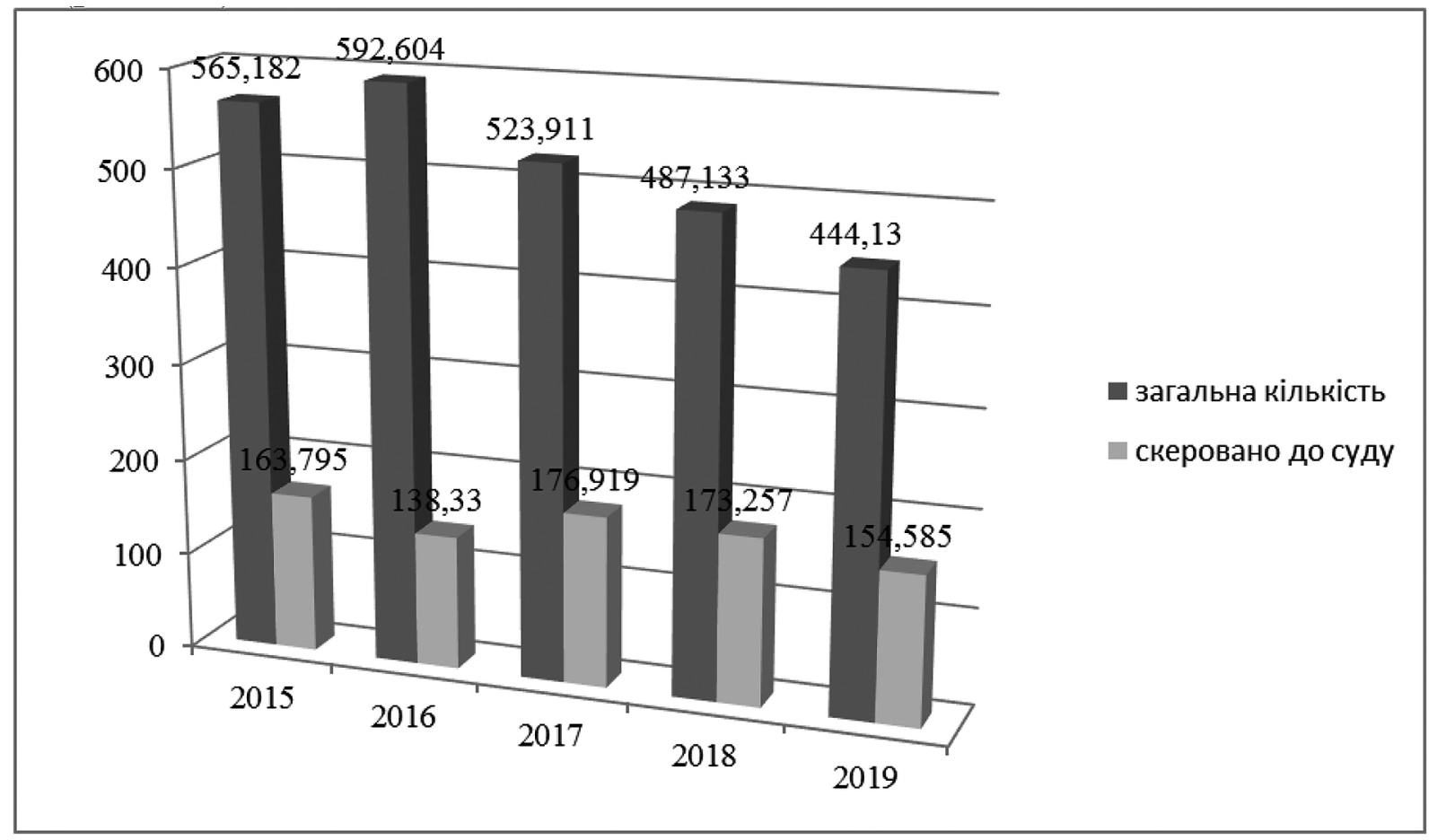

Рис. 2.2. Аналіз кримінальних правопорушень та їх розкриття у 2015 - 2019 роках [9]. 
Марисюк К.Б., Канцір В.С., Канцір І.А. - Насильство як деструктивний вектор...

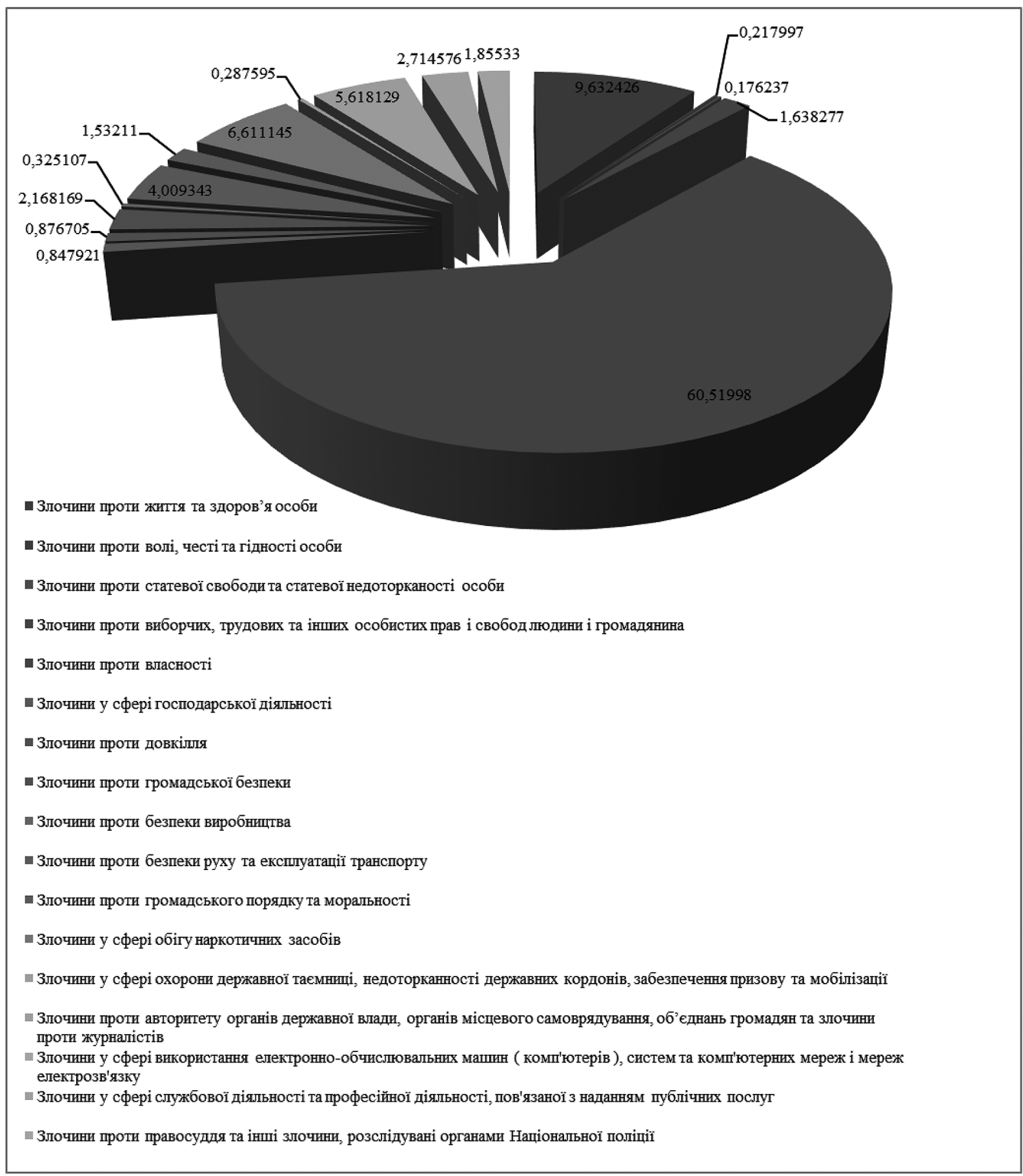

Рис. 2.3. Структура кримінальних правопорушень у 2019 році

За результатами офіційної статистичної інформації Генеральної прокуратури [9].

\section{Висновки}

Таким чином, насильство, у будь - яких проявах, - це завжди протиправний умисний вплив різної типології (фізичний, сексуальний, економічний, психологічний), на фізичну цілісність та/або особисту свободу іншого суб'єкта, на його статеву свободу чи недоторканність, фінансово-економічні інтереси. Вчиняється шляхом діяння, незалежно від того, чи воно усвідомлюється адресатом, опосередком заподіяння больових відчуттів, страждання, приниження й, відповідно, спричинення фізичної, психіч- 


\begin{tabular}{|c|}
\hline 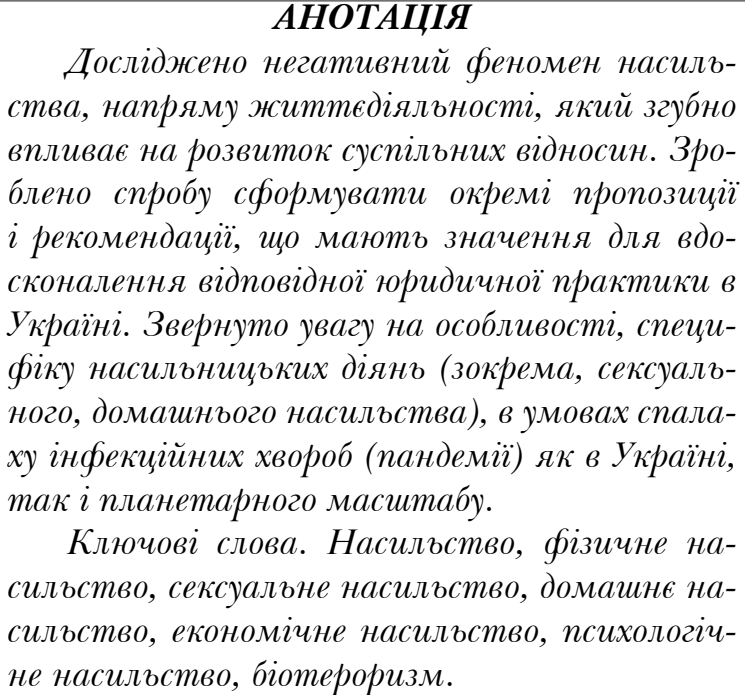 \\
\hline
\end{tabular}

ної, особистісно - моральної, фінансово-економічної шкоди.

Неможливо оминути увагою висновок, хоч і дотичний до окресленої проблематики, але надзвичайно актуальний у сьогоднішній час: стосовно негативного феномену - біотероризму, різновиду колективного насильства. На платформі біотероризму, умисного розповсюдження планетарного спалаху інфекційних хвороб, з метою ураження максимальної, абсолютно невизначеної кількості жертв, обвалу сталих фінансово-економічних інституцій, можна розглядати всі згадані ознаки насильства у своїй сукупності.

\section{Лiтература}

1. Marshall M. G. Global Report 2017: Conflict, Governance and State Fragility. M. G. Marshall, G. Elzinga-Marshall. 2017. URL: http://www.systemicpeace.org/vlibrary/GlobalReport2017.pdf.

2. Герасіна $\lambda$. М. Насильство як соціальна деструкція. Вісник ХНУ імені В. Н. Каразіна. Серія «Сочіологічні дослідження сучасно$2 о$ суспільства: методологія, теорія, методи». 2015. №1148. C. 35-40. URL: https://periodicals.karazin.ua/ssms/article/view/4464.
The negative phenomenon of violence, the direction of life activity, which has a detrimental effect on the development of social relations, is investigated. An attempt has been made to formulate specific proposals and recommendations that are relevant for the improvement of an appropriate legal practice in Ukraine. Attention is paid to the peculiarities and specifics of violent actions (in particular, sexual, domestic violence), in conditions of an infectious disease outbreak (pandemic), both in Ukraine and on a planetary scale.

Keywords. Violence, physical violence, sexual abuse, domestic violence, economic violence, psychological violence, bioterrorism.

3. Гусейнов А. А. Понятия насилия и ненасилия. Вопросъ философии. 1994. № 6.C. $35-41$.

4. Кальницька К. О., Шакун Н. В. Насильство як соціальний феномен: соціальнопсихологічні причини та етико-моральні засади протидії. Проблеми політичної психологї. Вип. 6 (20). С. 19-32.

5. Шнейдер А.Б. Девиантное поведение детей и подростков. М.: Академический проект. Трикста, 2005. 336 с.

6. Словник термінів з правової конфліктології: Науково-довідкове видання. За ред. М.І. Панова, Ю.П. Битяка, А.М. Герасіної. Х.: Одіссей, 2006. 208 с.

7. Христенко В.Е. Психология поведения жертвы. Ростов н/Д: Феникс, 2004.$416 \mathrm{c}$.

8. Конвенція Ради Європи про запобігання насильству стосовно жінок і домашньому насильству та боротьбу з цими явищами та пояснювальна доповідь. URL: www.coe.int/ web/stop-violence-against-women-ukraine

9. Офіційний сайт Генеральної прокуратури України. URL: https://old.gp.gov.ua/ua/ stst.

10. National Centre for Victims of Crime. URL: https://victimsofcrime.org. 